\title{
Climate change and drought effects on rural income distribution in the Mediterranean: a case study for Spain
}

\author{
Sonia Quiroga and Cristina Suárez \\ Department of Economics, Universidad de Alcalá, Alcalá de Henares, Spain \\ Correspondence to: Sonia Quiroga (sonia.quiroga@uah.es)
}

Received: 1 February 2015 - Published in Nat. Hazards Earth Syst. Sci. Discuss.: 23 July 2015

Revised: 6 April 2016 - Accepted: 30 April 2016 - Published: 15 June 2016

\begin{abstract}
This paper examines the effects of climate change and drought on agricultural incomes in Spanish rural areas. Present research has focused on the effects of these extreme climatological events through response functions, considering effects on crop productivity and average incomes. Among the impacts of droughts, we focused on potential effects on income distribution. The study of the effects on abnormally dry periods is therefore needed in order to perform an analysis of diverse social aspects in the long term. We estimate crop production functions for a range of Mediterranean crops in Spain and we use a measure of the decomposition of inequality to estimate the impact of climate change and drought on yield disparities. Certain adaptation measures may require a better understanding of risks by the public to achieve general acceptance. We provide empirical estimations for the marginal effects of the two impacts considered: farms' average income and income distribution. Our estimates consider crop production response to both biophysical and socioeconomic aspects to analyse long-term implications on competitiveness and disparities. As for the results, we find disparities in the adaptation priorities depending on the crop and the region analysed.
\end{abstract}

\section{Introduction}

Climate-change-induced impacts on society have captured an important part of the attention of environmental research in the last decades, usually estimated in a two-step process, where in a first phase physical units are calculated (changes in crop yield, life expectancy, sea level rise, number of species, etc.), while in a second step macroeconomic models are employed in order to translate the first result into monetary units (Ciscar et al., 2011; Watkins et al., 2005). Market equilibrium approaches are avoided here. We consider the economic revenues of the farms directly to estimate the impact of drought on income inequality. We then make a projection in terms of these econometric results without any additional assumption about market behaviour. In general, individuals and firms are modelled as representative agents within, respectively, one region and one market sector. This implies assuming the same socio-economic types of preferences across the world and across economies (Michetti and Zampieri, 2014). As an alternative we consider market issues directly through incomes at farm level which may reveal another part of the picture. This is also interesting in order to understand the expected impacts over producers.

Even if income inequality has been revealed as one of the most important drivers for significant changes in the socio-political framework in the European Union (EU) after the 2008 economic crisis and with equitable growth now at the forefront of economic debate (Piketty, 2013), not so much attention has been placed on the distributional effects of climate change extreme events and hazards on economic outputs. Economic evaluation efforts have been focused on risks at the average level, but it is becoming clear that adaptation policy needs to face climate-driven income inequality (Quiroga et al., 2015). There are important references in literature pointing towards an increase in food inequality induced by climate change (Wheeler and von Braun, 2013; Pindyck, 2013; Marino and Ribot, 2012) based on non-monetary units like yields or ingested calories. To date there has been little empirical research on how and where climate change interventions are shaping income inequality. This is indeed important in the agricultural sector due to its intrinsical link to rural development. It is also relevant in 
terms of EU Common Agricultural Policy (CAP, 2nd Pillar) and it is closely related to ecosystem conservation at the same time - through decoupling subsidies and developing agro-environmental programmes, which also affect forest area, that has significantly increased in Spain in the last decade as a result of land abandonment, with implications for conservation policies, forest landscape connectivity, etc. (Martín-Martín et al., 2013). Crop yield changes, as a response to climate change projections, have been estimated in many relevant studies dealing with climate change impacts (Rosenzweig et al., 2004; González-Zeas et al., 2014; Lobell et al., 2014), and the Mediterranean region in particular has been identified as a major hotspot due to the expected increase in drought risk (Garrote et al., 2007). As for the Spanish case, climate change will probably increase water conflicts among sectors, as well as an improvement in the efficiency of water use, which will be essential to maintain environmental flows and therefore ecosystem sustainability. In this context we have analysed the response of rain-fed crops to climate conditions including extreme events such as drought. Here we have selected crops best representing Mediterranean crop systems. Cereals, grapes, and olives are the three basic products of Mediterranean agriculture, the ones representing a higher proportion of harvested area, but also with an important cultural heritage in the region. Table 1 shows the percentage of total agricultural rain-fed area dedicated to the selected crops. We can see that they account for more than $50 \%$ of the rain-fed crop systems. Although agriculture does not represent a high proportion of gross domestic product (GDP) in Spain (less than $3 \%$ ), more than 3000 farms highly depend on these crops as their main activity. Due to the significant agricultural land abandonment in Spain (Beilin et al., 2014) the economic effects on these three crops are also important for the wider analysis of rural development.

Our main goal of the paper is to study drought-induced changes in the distribution of incomes that are based on agricultural output. We estimate crop production functions to simulate factor productivity in order to then calculate the response of income distribution to climate change. Particular attention is directed towards the economic outputs of crops. The value of production (in monetary units) is what we consider a change in income. The database we analyse provides results on the monetary value of production, which is used to check the factors' productivity, which is general practice when the focus is on the monetary units instead of physical units. This choice is important here since results allow us to analyse the change in the monetary units as a response to changes in the determinants (both observable and not observable).

Production is usually affected by unobserved factors. The way in which these influences can be separated from the effects of more tangible and traditional inputs - such as land, labour, or capital - is at the heart of a new debate. Different approaches to the appropriate identification strategies for
Table 1. Cultivation of cereals, grapes, and olives in Spain.

\begin{tabular}{lccc}
\hline & $\begin{array}{c}\text { Area in } \\
\text { Spain } \\
\left(10^{6} \text { ha }\right)\end{array}$ & $\begin{array}{c}\text { Percentage } \\
\text { of total } \\
\text { agricultural } \\
\text { rain-fed area }\end{array}$ & $\begin{array}{c}\text { Number of } \\
\text { farms in } \\
\text { the study }\end{array}$ \\
\hline Total agricultural & & & \\
rain-fed area & 13.7 & - & - \\
Cereals & 5.0 & 37 & 2250 \\
Grapes & 1.9 & 14 & 503 \\
Olives & 0.7 & 5 & 401 \\
Total of all three crops & 7.7 & 56 & 3154 \\
\hline
\end{tabular}

Source: MAGRAMA (2015) and own elaboration.

addressing endogeneity and collinearity problems have appeared over the last years. The aim is to avoid simultaneity and selection biases that are common in most production function estimates (Petrick and Kloss, 2013; Yasar et al., 2008). We estimate the production function using the approach provided by Olley and Pakes (1996), which allows control of both traditional inputs and state variables - such as climate - to be combined and different kinds of biases to be avoided, such as those resulting from the exit of inefficient farms. This model allows the effect of unobservable inputs such as soil quality, human capital of the labour force, farmer's effort, etc, to be accounted for.

Our study is centred on Spanish farms located in the Mediterranean agroclimatic region. The present situation does not allow for much optimism. Explicit restrictions on water availability have been introduced in most of the Spanish river basins and there are big socio-economic conflicts, especially in the agricultural sector. Extraordinarily bad governance practices related to water and irrigators have been reported, especially in relation to water rights in Spain. In the Tagus river basin, especially in the case of Western Mancha, the lack of clear definition of water rights currently creates critical conflicts with estimated thousands of illegal abstractors. To achieve more effective water governance in the area, it is necessary to create an enabling environment, which facilitates efficient private and public sector initiatives and stakeholder involvement in articulating needs (De Stefano et al., 2013; Rogers et al., 2006).

This paper is organized as follows: Sect. 2 focuses on the steps within the methodology, models, and data. Section 2.1 details the climate change scenarios considered for the simulations; Sect. 2.2 presents the econometric model for the Olley and Pakes crop production estimation, Mediterranean crops, and Gini index decomposition. Section 2.3 explains the Gini index for measuring income distribution and the decomposition for calculating the marginal effects of drought. Sections 3.1 to 3.3 present the results for the production functions, the simulations of marginal effects of drought for the different scenarios, and the calculations for the changes in farms' income distribution. 


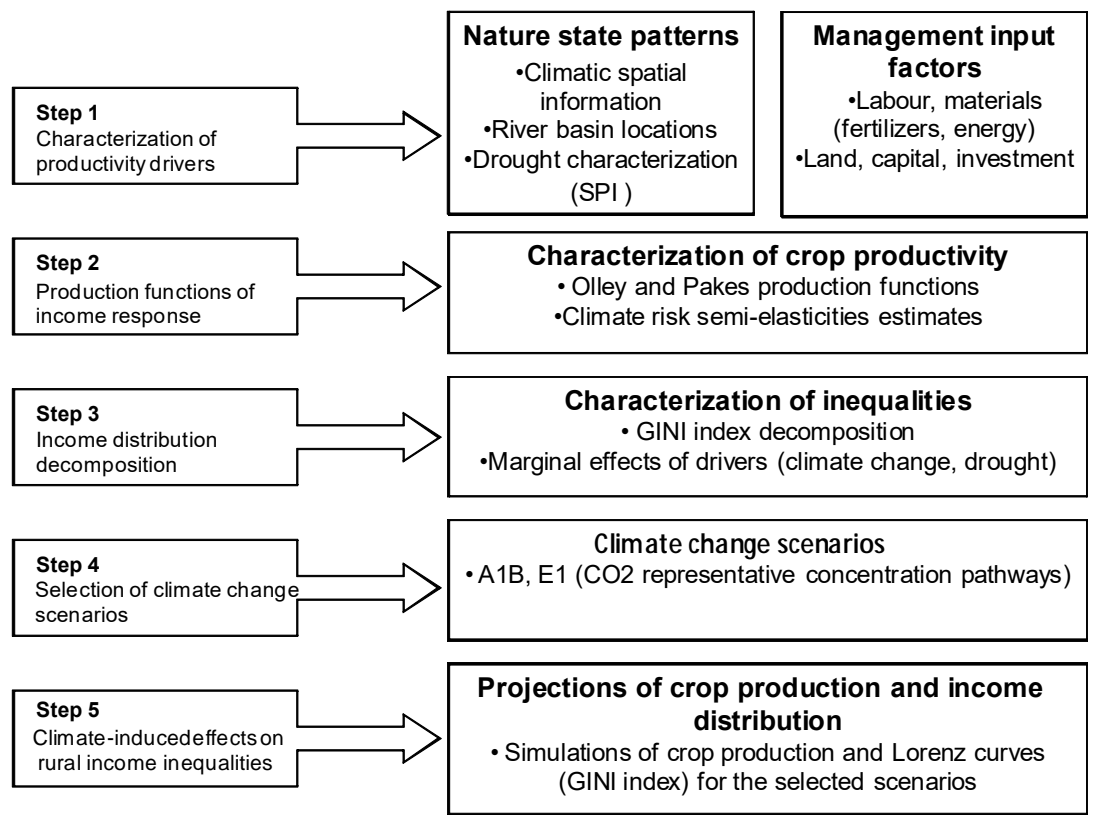

Figure 1. Steps of methodology.

\section{Methods}

This paper provides an assessment of income distribution as a response to a climate-change-induced increase in droughts in the Mediterranean. Our analysis integrates two essential components of the economic perspective of adaptation policy: productivity and equity. We first analyse the drivers for the agricultural systems' production through a semiparametric method using 1990-2013 data for production in monetary terms at the farm level in different river basins in Spain. We have integrated biophysical and socio-economic databases to characterize the nature state variables and management factors. Second, we explore the distributional aspects computing the marginal effect of changes on seasonal rainfall distribution, using a decomposition of the standard Gini coefficient to then simulate production and income distribution according to these climate scenarios. Figure 1 summarizes the steps on the methodology.

\subsection{Agricultural production function simultaneous estimates: observed inputs and unobserved productivity shocks}

We first need to define and estimate a production function. The Olley and Pakes (1996) approach assumes that incumbent farms decide at the beginning of each period whether to continue to participate in farming activity depending on their productivity level, which in turn depends on their production factors (it corrects the selection bias). To this end, investment $\left(i_{i t}\right)$ is considered as a proxy for the unobserved productivity shocks. Additionally, this method corrects the simultaneity bias arising from the fact that farms choose their level of input once they know their level of productivity. Most of the studies in the literature using Olley-Pakes methodology assume a Cobb-Douglas production function (see Rizov et al., 2013 and Kazukauskas et al., 2010, as recent examples focused on EU farm data). Since this is the functional form more commonly accepted, we assumed it for our study. The robustness of this method has been proved previously in Petrick and Kloss (2013). Simultaneity exists between the choice of inputs and productivity since productive farms are more likely to make capital investments to increase the future value of the farm. Therefore, the farm's decision to invest in further capital implies that future productivity is increasing in the current productivity shock, so farms that experience a large positive productivity shock in period $t$ will invest more in period $t+1$. The Olley and Pakes (1996) semiparametric method accounts for these issues.

There is also a selection bias caused by the fact that farms only stay in business if the liquidation value is smaller than the anticipated future value of profits. Controlling for this selection bias requires a second step to estimate survival probabilities. In our implementation, we estimate the probability of survival by fitting a Probit model. Details on the production function are reported in Appendix A. In order to analyse the effects of climate we can examine these coefficients that represent climate elasticity (or semi-elasticity to be more precise), that can be defined as the percentage change in the function's output as a result of a one-unit change in the level of a climate variable. For example, the average temperature coefficient indicates the percentage change in monetary outcome for the farms due to an increase in $1{ }^{\circ} \mathrm{C}$ in the average temperature. 
Marginal product - the change in output resulting from employing one more unit of a particular input, assuming other variables are kept constant (Brewer, 2010) - has been calculated for when the drought effect is analysed.

\subsection{Measuring rural income distribution: a decomposition of the Gini index with regard to social equity}

To characterize the inequality level generated by agricultural output, we use the Gini coefficient decomposition proposed by Pyatt et al. (1980) and Shorrocks (1982), and extended by López-Feldman et al. (2007), which includes the marginal effects of different sources on overall yield inequality, focusing on the impact of water-related variables. The Gini coefficient is probably the most common inequality measure because of its simplicity and its desirable properties. In a general context, it fulfils the properties of mean independence, population size independence, symmetry, and Pigou-Dalton transfer sensitivity (Haughton and Khandker, 2009). However, this tool presents two main shortcomings: (i) difficult decomposability as entropy measures, and (ii) difficult statistical testability for the significance of changes in the index over time. Haughton and Khandker (2009) suggested that the latter is not a real problem because confidence intervals can usually be produced by means of bootstrap techniques. Taking these considerations into account, we use this approach. This concentration ratio is widely used in many fields of economics as well as in ecology and agronomics, but there are fewer applications in agricultural and environmental economics together (Quiroga et al., 2014; Sadras and Bongiovanni, 2004; Seekell et al., 2011). In a general context, it ranges from zero (equal distribution) to one (perfect inequality).

The decomposition of the overall Gini into specific source factor effects was derived from Lerman and Yitzhaki (1985). It is a good measure to help to understand the determinants of inequality, and allows the effect of small changes in a specific source of yield (or, in this case, income) on inequality to be estimated, while the other sources' constant is maintained. In this paper, we include drought as a source factor. If we consider the relationship between drought and crop yield, the interpretation of Gini decomposition will be the following: (i) if drought as a source represents a large share of total crop yield, it could probably have a large impact on inequality; (ii) if crop yield is equally distributed, it cannot affect inequality, even if its magnitude is large; and (iii) if this crop yield source is large and unequally distributed, it could either increase or decrease inequality, depending on which farmers, at which points in the crop yield distribution, earn it.

Here we use the Lorenz curves as the most common Gini index representation to analyse how rural inequality responds to climate-change-induced drought. The Lorenz curves represent the cumulative distribution function of income distribution. Since a perfectly equal income distribution would be one in which every farmer has the same income, this could be represented by the line $y=x$, also called the "perfect equality" or "equi-distribution" line. In this hypothetical case, $N \%$ of rural population would always have $N \%$ of the rural income. The Gini index corresponds to the area between the Lorenz curve and the equi-distribution line.

A detailed description of Gini decomposition can be found in Appendix B.

\subsection{Data}

Since our model considers the interrelation among management factors and climate state variables, it was necessary to combine several socio-economic and biophysical databases for the analysis. Table 2 shows detailed information about the variables we used, the units and source of the data, and main descriptive statistics. We have used the SABI database (Iberian Balance sheet Analysis System), which provides information about farm production in monetary terms, management factors (land, labour, and capital), and spatial farm location. The SABI database is produced jointly by Bureau van Dijk and Informa and comes from the financial information that farms must present to the Companies Registration Office. It is an annual survey which looks at a panel of representative Spanish agricultural farms and contains balance sheet data, cash flow, and other data. Our database is an unbalanced panel observed over the period 1990-2013. The most difficult issue with an unbalanced panel is precisely determining the origin of the lack of balance: (1) if the reason a farm leaves the sample is not correlated with the idiosyncratic error (those unobserved factors that change over time and affect profits), then the unbalanced panel causes no problems. (2) If the reason a farm leaves the sample is correlated with the idiosyncratic error, then the resulting sample can cause biased estimators. One advantage of the mechanics of Olley and Pakes (1996) (as it is explained in the Appendix A) is that it takes into account the selection bias resulting from the exit of inefficient farms.

SABI also provides information about the major digit NACE codes (National Classification of Economic Activities) to which the farms belong. The data are at the farm level and they are provided for different sectors. Here we have analysed the farms from 1990 to 2013 in the most important sectors regarding Mediterranean representative crops: the cereal sector (NACE code A1.1.1), the grape sector (NACE code A1.2.1), and the olive sector (NACE code A1.2.6). Our sample includes all the farms providing information for the selected sectors.

The SABI database provides the data in real currency (current EUR), so to consider real increase in purchase capacity and discount the effect of market price increases, we have deflated the current monetary variables into real values with 1990 as the base year, using national account data for Spain (INE, Spanish National Statistics Bureau). Climatic information for the period 1990-2013 has been collected from 
Table 2. Description and descriptive statistics of the variables used in the analysis.

\begin{tabular}{|c|c|c|c|c|c|c|c|c|c|c|}
\hline \multirow[t]{2}{*}{ Type } & \multirow[t]{2}{*}{ Name } & \multirow[t]{2}{*}{ Definition } & \multirow[t]{2}{*}{ Unit } & \multirow[t]{2}{*}{ Source $\left({ }^{*}\right)$} & \multicolumn{2}{|c|}{ Cereals } & \multicolumn{2}{|c|}{ Grapes } & \multicolumn{2}{|c|}{ Olives } \\
\hline & & & & & Mean & SD & Mean & SD & Mean & $\mathrm{SD}$ \\
\hline \multirow{7}{*}{ 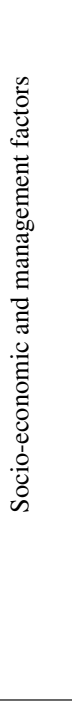 } & $Y_{i t}$ & $\begin{array}{l}\text { Total crop } \\
\text { production at } \\
\text { farm } i \text { in year } t\end{array}$ & $\begin{array}{l}\text { Thousands } \\
\text { of } 1990 \text { EUR }\end{array}$ & SABI, INE & 330.9 & 1470.7 & 263.5 & 766.2 & 181.4 & 375.8 \\
\hline & $L_{i t}$ & $\begin{array}{l}\text { Total employment } \\
\text { at farm } i \text { in year } t\end{array}$ & $\begin{array}{l}\text { Number of } \\
\text { workers }\end{array}$ & SABI, INE & 8.9 & 29.8 & 7.6 & 29.8 & 9.8 & 14.3 \\
\hline & $M_{i t}$ & $\begin{array}{l}\text { Materials (fertilizers, } \\
\text { pesticides, energy, etc.) }\end{array}$ & $\begin{array}{l}\text { Thousands } \\
\text { of } 1990 \text { EUR }\end{array}$ & SABI, INE & 276.5 & 1274.4 & 200.3 & 684.3 & 125.7 & 362.1 \\
\hline & $K_{i t}$ & $\begin{array}{l}\text { Capital assets } \\
\text { (machinery, } \\
\text { tractors, etc.) }\end{array}$ & $\begin{array}{l}\text { Thousands } \\
\text { of } 1990 \text { EUR }\end{array}$ & SABI, INE & 647.1 & 1480.6 & 707.7 & 1471.9 & 821.2 & 1740.0 \\
\hline & $A_{i t}$ & Land & $\begin{array}{l}\text { Thousands } \\
\text { of } 1990 \text { EUR }\end{array}$ & SABI, INE & 196.3 & 1530.4 & 192.8 & 777.6 & 139.1 & 788.5 \\
\hline & $I_{i t}$ & Investment & $\begin{array}{l}\text { Thousands } \\
\text { of } 1990 \text { EUR }\end{array}$ & $\begin{array}{l}\text { Own } \\
\text { elaboration } \\
\text { from SABI }\end{array}$ & 93.1 & 608.6 & 115.0 & 444.1 & 108.3 & 617.9 \\
\hline & $t$ & $\begin{array}{l}\text { Time trend: } \\
t=1 \text { for } 1991, \\
t=23 \text { for } 2013\end{array}$ & $\begin{array}{l}\text { Year } \\
\text { sequence }\end{array}$ & $\begin{array}{l}\text { Own } \\
\text { elaboration }\end{array}$ & - & - & - & - & - & - \\
\hline \multirow{12}{*}{ 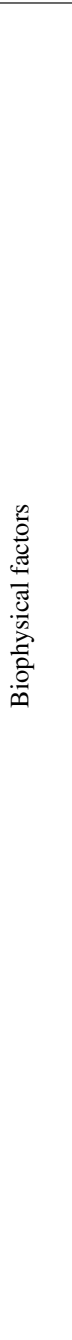 } & $\mathrm{T}_{-} \operatorname{son}_{i t}$ & $\begin{array}{l}\text { Average seasonal } \\
\text { temperature at } \\
\text { site } i \text { in the year } t \\
\text { (Sept, Oct, Nov) }\end{array}$ & ${ }^{\circ} \mathrm{C}$ & AEMET & 16.9 & 2.7 & 16.3 & 2.6 & 17.9 & 2.0 \\
\hline & $\mathrm{T}_{-} \mathrm{djf}_{i t}$ & $\begin{array}{l}\text { Average seasonal } \\
\text { temperature at } \\
\text { site } i \text { in the year } t \\
\text { (Dec, Jan, Feb) }\end{array}$ & ${ }^{\circ} \mathrm{C}$ & AEMET & 8.5 & 3.0 & 7.9 & 2.8 & 9.5 & 2.3 \\
\hline & Prec_son $i t$ & $\begin{array}{l}\text { Total seasonal } \\
\text { precipitation at } \\
\text { site in the year } t \\
\text { (Sep, Oct, Nov) }\end{array}$ & $\mathrm{mm}$ & AEMET & 154.2 & 78.4 & 171.8 & 103.9 & 167.8 & 85.3 \\
\hline & Prec_def ${ }_{i t}$ & $\begin{array}{l}\text { Total seasonal } \\
\text { precipitation at } \\
\text { site } i \text { in the year } t \\
\text { (Dec, Jan, Feb) }\end{array}$ & $\mathrm{mm}$ & AEMET & 139.2 & 124.8 & 129.0 & 118.4 & 175.9 & 149.3 \\
\hline & Prec_mam ${ }_{i t}$ & $\begin{array}{l}\text { Total seasonal } \\
\text { precipitation at } \\
\text { site in the year } t \\
\text { (Mar, Apr, May) }\end{array}$ & $\mathrm{mm}$ & AEMET & 131.8 & 60.3 & 143.5 & 79.6 & 147.1 & 72.4 \\
\hline & Prec_jja ${ }_{i t}$ & $\begin{array}{l}\text { Total precipitation } \\
\text { at a site in the year } t \\
\text { (Jun, Jul, Aug) }\end{array}$ & $\mathrm{mm}$ & AEMET & 37.6 & 39.8 & 56.2 & 49.4 & 26.3 & 35.9 \\
\hline & Drought $_{i t}$ & $\begin{array}{l}\text { Dummy variable } \\
\text { ( } 1 \text { for dry years, } \\
0 \text { in other cases) }\end{array}$ & $\begin{array}{l}1 \text { or } 0 \text { as } \\
\text { a function of } \\
\text { SPI }\end{array}$ & $\begin{array}{l}\text { Own } \\
\text { elaboration } \\
\text { from AEMET }\end{array}$ & $55.0 \%$ & - & $49.0 \%$ & - & $54.1 \%$ & - \\
\hline & River_basin $_{i}$ & $\begin{array}{l}\text { Dummy variables for } \\
\text { river basin selection: } \\
\text { (1) Duero }\end{array}$ & $\begin{array}{l}1 \text { or } 0 \text { as } \\
\text { a function } \\
\text { of the area }\end{array}$ & $\begin{array}{l}\text { Own } \\
\text { elaboration } \\
\text { from SABI }\end{array}$ & & & & & & \\
\hline & & $\begin{array}{l}\text { (1) Duero } \\
\text { (2) Ebro }\end{array}$ & & & $\begin{array}{l}5.8 \% \\
12.8 \%\end{array}$ & $\begin{array}{l}- \\
-\end{array}$ & $14.1 \%$ & $\begin{array}{l}- \\
-\end{array}$ & $\begin{array}{l}0.6 \% \\
2.1 \%\end{array}$ & $\begin{array}{l}- \\
-\end{array}$ \\
\hline & & (3) Guadalquivir & & & $23.8 \%$ & - & $7.9 \%$ & - & $55.1 \%$ & - \\
\hline & & (4) Guadiana & & & $5.1 \%$ & - & $1.6 \%$ & - & $3.1 \%$ & - \\
\hline & & (5) Tajo & & & $26.6 \%$ & - & $24.6 \%$ & - & $16.8 \%$ & - \\
\hline
\end{tabular}

(*) Iberian Balance sheet Analysis System (SABI); Spanish National Statistics Bureau (INE), State Meteorological Agency in Spain (AEMET). SD denotes standard deviation. 
AEMET (State Meteorological Agency in Spain). Table 2 presents the descriptive analysis of the variables used.

The current work uses each firm's sales volume and it is converted into real terms. With regard to the inputs, labour is measured as the number of workers. In this type of study, the standard practice is to define labour in terms of hours worked but this information is not available. Capital quantity is defined as the market value of capital assets (machinery, tractors, etc.) owned by the farms, in constant prices. Land is defined as the real value in monetary terms for the planting area for every farm, so this is not constant during the considered period. Every year farms declare the value of their properties (which can be sold or bought). This value, expressed in real terms to avoid inflation effects, is what we consider as land input. Although we do not have information about real land use, which does not only depend on the variation of the amount and value of planting area but also on the competition between the use of a portion of land amongst different scopes (abandonment, urban, afforestation, food production, energy production etc.), which constitutes a limitation, we can capture the evolution of agricultural land value. Material is defined as intermediate spending carried out in the production process (fertilizers, pesticides, energy, etc.). The farm investment is calculated according to the proposal by Lewellen and Badrinath (1997) as follows:

$i_{i t}=\mathrm{nf}_{i t}-\mathrm{nf}_{i t-1}+\mathrm{bd}_{i t}$,

where $\mathrm{nf}$ is net fixed assets and bd is book depreciation expenses. Theoretically, the model mentioned in the last section requires investment to be strictly positive to invert the investment function. In their empirical implementation, Olley and Pakes (1996) drop all observations with zero investment. Other authors have noted that in practice, zero investment is often observed and that the methodology seems to work even when the theory is violated (see, for example, Pavcnik, 2002). Therefore, our approach will be to retain all the observations with zero investment but also introduce dummy variables (dummy variables for zero investment interacting with state inputs) to account for these observations, as in Blalock and Gertler (2004) and Breunig and Wong (2008). As a robusticity check, we estimated the model dropping all of the observations with zero investment and the resulting coefficient estimates, similar to those reported below. We add $t$, which is a variable included here to measure the Hicks-neutral technical change that is common among firms in the same sector and autonomous region. A Hicks-neutral technical change is a change in the production function of a farm that satisfies certain economic neutrality conditions. A change is considered to be Hicks-neutral if the change does not affect the balance of labour and capital in the products' production function. Factor-neutral (also called Hicksneutral) technological change is assumed, either explicitly or implicitly, in most of the standard techniques for measuring productivity, ranging from the classic growth decompositions of Solow (1957) and Hall (1988) to the recent structural estimators for production functions (Olley and Pakes, 1996; Levinsohn and Petrin, 2003; Ackerberg et al., 2006).

In our paper, we measure Hicks-neutral technological progress with the time trend in production function. Assuming neutral technical change implies that the coefficients of the interactions between the yearly trend and the input variables are zero. We also tried to estimate a non-neutral technical progress, but the resulting coefficients were not significant, so the Hicks-neutral technological progress was deemed appropriate.

Drought characterization is always a difficult task, given the spatial and temporal properties of drought and no single accepted definition (Tsakiris et al., 2007). In the most general sense, drought originates from a deficiency of precipitation over an extended period of time - usually a season or more - resulting in a water shortage for some activity group or environmental sector (NDMC, 2015). Operational definitions help define the onset, severity, and end of droughts. No single operational definition of drought works in all circumstances, and this is a big part of why policymakers, resource planners, and others have more trouble recognizing and planning for drought than they do for other natural disasters (NDMC, 2015). To characterize drought in this study, we take the commonly used Standardized Precipitation Index (SPI, McKee et al., 1993). Broadly considered, this index is based on the probability of precipitation for any timescale. It is calculated as the difference in accumulated precipitation between a selected aggregation period and the average precipitation for that same period. We have introduced the SPI in a dummy form since we are also interested in the direct effect of temperature and precipitation and we wanted to avoid collinearity problems with the SPI since it is constructed from precipitation data. This approach has been used before in some previous analysis in Spain (Iglesias and Quiroga, 2007; Quiroga and Iglesias, 2009; Iglesias et al., 2010; Garrote et al., 2007). We have used SPI to characterize drought since it is widely used and more comparable across regions with different climates than other more complex indexes such as the Palmer Drought Severity Index (PDSI). SPI does not consider temperature, which is responsible for affecting evapotranspiration, but we have considered temperature effects among the explanatory variables of the model. However, other limitations include SPI not considering the intensity of precipitation and its potential impacts on runoff, streamflow, and water availability within the system of interest (Keyantash and National Center for Atmospheric Research Staff, 2015).

We have introduced a geographical variable to capture the differences among river basin locations (Fig. 2) to reflect that climate and management patterns vary across the basins and so do the crop processes and farmers' incomes. All 10 river basins are represented in the analysis since there are a number of farms included in each of the basins. However, we introduced a dummy variable for differentiating the effects on five of them: Duero, Ebro, Guadalquivir, Guadiana, and Tajo. 


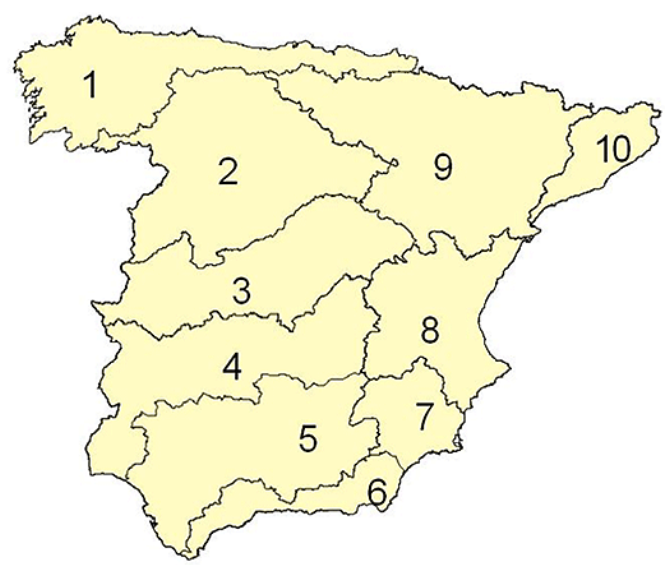

(1) Northern, (2) Duero, (3) Tagus, (4) Guadiana,

(5) Guadalquivir, (6) Andalusia, (7) Segura, (8) Jucar,

(9) Ebro, (10) Catalunya

Figure 2. Spanish river basins.

This allows us to compare differential marginal effects for these important basins. For example, if we have a significant and positive effect on the variable capturing the Duero river basin effect, this indicates that for this basin the effects are higher than the average effects. For the river basins not represented we just have the average value as reference. Introducing dummy variables allocates differential marginal effects with respect to the representative average value. We consider the most important river basins to allocate these differences.

\subsection{Climate change scenarios and drought in the Mediterranean}

We analyse the response of crop production to climate change through simulations responding to climate scenarios derived from Representative Concentration Pathways of global emissions for the 2050s, the A1B scenarios with a balanced emphasis on all energy sources (around $850 \mathrm{ppm}$ of $\mathrm{CO}_{2}$ ) and the $\mathrm{E} 1$ scenarios representing stabilization (458 ppm of $\mathrm{CO}_{2}$ ); although basin-level data have not been developed for the new representative concentration pathways (RCPs) in Spain (as can be seen at Rogelj et al., 2012), the equivalence can suggest that $\mathrm{A} 1 \mathrm{~B}$ ranges between RCP and RCP8.5, and E1 corresponds to RCP4.5. Although this paper focuses on the priorities for adaptation, we want to place these priorities in terms of mitigation efforts. Adaptation and mitigation are dependent on each other (IPCC, 2014). The greater the effort in mitigation (i.e. a more stringent target is foreseen in $\mathrm{CO}_{2}$ concentration reduction in 2100), the lower the cost of adaptation to climate change will be (although, of course, some unavoidable effects remain independent of mitigation efforts). The source of climate data is the University of East Anglia (Christensen et al., 2011) and these data have been fully described in Iglesias et al. (2012a). A1B represents a balanced emphasis on all energy sources with
$\mathrm{CO}_{2}$ level in 2080 of about $850 \mathrm{ppm}$. E1 is the so-called global " $2{ }^{\circ} \mathrm{C}$ stabilization" scenario that is characterized by atmospheric concentrations of $498 \mathrm{ppm} \mathrm{CO}_{2}$ in the 2080s. These last-generation socio-economic scenarios were not developed in the PRUDENCE project but new climate projections have been developed under the Climate Cost project (Christensen et al., 2011; Iglesias et al., 2012a). To address uncertainty we use several climate models driven by these Representative Concentration Pathways: A1B: DMIEH5-4; A1B:HADGEM-1 and the E1: DMICM3-1; E1: DMICM32; E1: HADGEM2-1.

Table 3 presents the average values for the seasonal average temperatures and total precipitations.

The two selected scenarios represent important differences in mitigation policies. The E1 scenario corresponds to the future emission pathway that is required to limit global warming to no more than $2{ }^{\circ} \mathrm{C}$ above pre-industrial levels and the allowable level of $\mathrm{CO}_{2}$ emissions in this greenhouse gas stabilization scenario corresponds to limiting global warming below this EU target. Significant and early policy actions are required in mitigating greenhouse gas emissions to limit global warming to no more than $2{ }^{\circ} \mathrm{C}$ above pre-industrial levels. In the greenhouse gas stabilization, the allowable $\mathrm{CO}_{2}$ emissions increase has to be steadily reduced, resulting in a decrease of $56 \%$ in year 2050 and almost $100 \%$ in year 2100. (Roeckner et al., 2011). On the other hand, the A1B scenario is part of the Special Report on Emissions Scenarios (SRES) scenario families and has been the focus of model intercomparison studies. E1 and A1B illustrative marker scenarios are about 490 and 850 ppm respectively (IPCC, 2007; Christensen et al., 2011; Roeckner et al., 2011). Since the European Union is targeting important efforts for mitigation, we have focused on scenarios in line with recent policy agreements.

Drought projections have been made considering the projected expected changes in precipitation patterns as a result of climate change. SPI has been calculated from climate change projections for the selected scenarios. In addition, since we want to consider the general effect of temperature variation due to climate change, we have also included the climate variables directly as determinants.

\section{Results}

\subsection{Olley and Pakes production functions' estimates}

Table 4 shows the estimates for the nature state drivers and management factors' elasticities of the statistical function of yield response for the selected Mediterranean crops in the analysis. We observe that the marginal effects are as expected with regard to traditional inputs; that is, the management factors positively affect the increase in productivity. We observe that the effect of size (land) is not relevant in determining crop production in Spain; that is, there are not significant 
Table 3. Climate change scenarios: average values for medium temperature and total precipitation under the selected climate change scenarios for the period 2070-2100. GCMs denote general circulation models.

\begin{tabular}{|c|c|c|c|c|c|c|c|c|c|c|}
\hline $\begin{array}{l}\text { Emission } \\
\text { scenario }\end{array}$ & $\begin{array}{l}\text { GCM/ } \\
\text { downscaling }\end{array}$ & $\begin{array}{c}\mathrm{CO}_{2} \\
\text { targets }(2050) \\
(\mathrm{ppm})\end{array}$ & $\begin{array}{r}\text { Prec_son } \\
(\mathrm{mm})\end{array}$ & $\begin{array}{r}\text { Prec_djf } \\
(\mathrm{mm})\end{array}$ & $\begin{array}{r}\text { Prec_mam } \\
(\mathrm{mm})\end{array}$ & $\begin{array}{r}\text { Prec_jja } \\
(\mathrm{mm})\end{array}$ & $\begin{array}{c}T_{\_} \text {son } \\
\left({ }^{\circ} \mathrm{C}\right)\end{array}$ & $\begin{array}{l}T \_ \text {djf } \\
\left({ }^{\circ} \mathrm{C}\right)\end{array}$ & $T$ _mam & $\begin{array}{l}T_{\_ \text {jja }} \\
\left({ }^{\circ} \mathrm{C}\right)\end{array}$ \\
\hline A1B & BCM2_1 & 850 & -73.3 & -41.0 & -83.4 & -40.5 & 2.3 & 1.9 & 3.0 & 3.3 \\
\hline A1B & CNCM3_1 & 850 & -77.3 & -54.8 & -105.5 & -77.0 & 3.5 & 2.1 & 3.5 & 4.9 \\
\hline A1B & DMIEH5_4 & 850 & -81.9 & -88.0 & -92.4 & -149.9 & 4.1 & 2.3 & 3.1 & 5.2 \\
\hline A1B & EGMAM_1 & 850 & -13.5 & 10.2 & -100.1 & -68.9 & 3.2 & 2.7 & 2.8 & 3.7 \\
\hline E1 & BCM2_1 & 490 & -58.2 & -47.2 & -24.6 & -11.1 & 1.1 & 1.0 & 0.9 & 1.5 \\
\hline E1 & CNCM3_1 & 490 & -56.7 & -8.9 & -70.7 & 1.9 & 1.3 & 0.8 & 1.0 & 1.4 \\
\hline E1 & DMIEH5_4 & 490 & -11.9 & 17.5 & -11.9 & -0.2 & 1.3 & 1.6 & 1.4 & 1.6 \\
\hline E1 & EGMAM_1 & 490 & 4.7 & -6.1 & -31.8 & -58.8 & 1.7 & 1.2 & 1.2 & 1.6 \\
\hline
\end{tabular}

Table 4. Olley-Pakes estimates for the factors' elasticities of the statistical function of income response for cereal, grape' and olive sectors (baseline: 1991-2013).

\begin{tabular}{|c|c|c|c|c|c|c|}
\hline & \multicolumn{2}{|c|}{ Cereals } & \multicolumn{2}{|c|}{ Grapes } & \multicolumn{2}{|c|}{ Olives } \\
\hline & Coef & SE & Coef & SE & Coef & SE \\
\hline Land & -0.0452 & $(0.036)$ & 0.1237 & $(0.142)$ & -0.0285 & $(0.077)$ \\
\hline Capital & -0.0497 & $(0.020)^{b}$ & 0.0381 & $(0.086)$ & 0.0521 & $(0.086)$ \\
\hline Labour & 0.2935 & $(0.017)^{\mathrm{a}}$ & 0.3814 & $(0.032)^{\mathrm{a}}$ & 0.2827 & $(0.032)^{\mathrm{a}}$ \\
\hline Material & 0.7805 & $(0.015)^{\mathrm{a}}$ & 0.6440 & $(0.033)^{\mathrm{a}}$ & 0.6743 & $(0.044)^{\mathrm{a}}$ \\
\hline$T$ & -0.0012 & $(0.002)$ & -0.0069 & $(0.005)$ & -0.0113 & $(0.008)$ \\
\hline$T \_$son & - & - & - & - & 0.0406 & $(0.017)^{\mathrm{b}}$ \\
\hline$T \_$djf & - & - & -0.0243 & $(0.013)^{\mathrm{c}}$ & -0.0551 & $(0.016)^{\mathrm{a}}$ \\
\hline$T \_$mam & -0.0189 & $(0.008)^{b}$ & - & - & - & - \\
\hline Prec_son & -0.0001 & $(0.000)$ & 0.0002 & $(0.000)$ & -0.0002 & $(0.000)$ \\
\hline Prec_def & -0.0001 & $(0.000)^{b}$ & -0.0003 & $(0.000)$ & 0.0000 & $(0.000)$ \\
\hline Prec_mam & 0.0002 & $(0.000)$ & 0.0002 & $(0.000)$ & 0.0004 & $(0.000)$ \\
\hline Prec_jja & 0.0006 & $(0.000)^{\mathrm{c}}$ & 0.0008 & $(0.000)^{\mathrm{a}}$ & -0.0006 & $(0.001)$ \\
\hline Drought & -0.0309 & $(0.019)^{\mathrm{c}}$ & -0.0178 & $(0.029)$ & -0.0860 & $(0.051)^{\mathrm{c}}$ \\
\hline Duero & 0.0767 & $(0.052)$ & -0.0175 & $(0.114)$ & -1.3191 & $(0.602)^{b}$ \\
\hline Ebro & 0.1224 & $(0.045)^{\mathrm{a}}$ & 0.0173 & $(0.078)$ & 0.2656 & $(0.129)^{b}$ \\
\hline Guadalquivir & 0.0434 & $(0.035)$ & 0.0156 & $(0.116)$ & 0.0605 & $(0.083)$ \\
\hline Guadiana & 0.0225 & $(0.059)$ & 0.4534 & $(0.150)^{\mathrm{a}}$ & 0.1171 & $(0.198)$ \\
\hline Tajo & -0.2184 & $(0.048)^{\mathrm{a}}$ & -0.0776 & $(0.073)$ & -0.2626 & $(0.101)^{\mathrm{a}}$ \\
\hline Obs & \multicolumn{2}{|c|}{17157} & \multicolumn{2}{|c|}{3488} & \multicolumn{2}{|c|}{3028} \\
\hline Farms & \multicolumn{2}{|c|}{2250} & \multicolumn{2}{|c|}{503} & \multicolumn{2}{|c|}{401} \\
\hline
\end{tabular}

Note: standard errors (SEs) in OP model are bootstrapped using 50 replications. ${ }^{\text {a }}$ Significant at the $1 \%$ level. ${ }^{\mathrm{b}}$ Significant at the $5 \%$ level. ${ }^{\mathrm{c}}$ Significant at the $10 \%$ level. Coef denotes the coefficient.

productivity differences between big and small farms. This result is quite common in literature (Petrick and Kloss, 2013; Yasar et al., 2008). With regard to climate drivers, we find in general that average temperatures have a positive effect and the same is true for precipitation. Droughts appear to be the most important factor for external productivity shocks. In addition, we have tested collinearity problems between precipitation variables and SPI and considering the matrix of cor- relations and the variance inflation factors, we conclude that there is no problem among factors to be concerned about.

This effect is crop-specific and it is more important in the case of olives. This is due to the climatic conditions of this rain-fed Mediterranean crop, located basically in the southern areas which have critical water availability shortages during drought. 
Table 5. Gini decomposition for drought by crop and river basin.

\begin{tabular}{llcccccc}
\hline Crop & River basin & $G$ & $S_{k=\text { Drought }}$ & $G_{k=\text { Drought }}$ & $R_{k=\text { Drought }}$ & \% Change & [95\% conf. interval] \\
\hline \multirow{5}{*}{ Cereals } & Duero & 0.561 & 0.003 & 0.413 & -0.051 & -0.32 & {$[-0.35-0.28]$} \\
& Ebro & 0.704 & 0.002 & 0.424 & -0.022 & -0.21 & {$[-0.23-0.18]$} \\
& Guadalquivir & 0.729 & 0.002 & 0.398 & -0.039 & -0.17 & {$[-0.19-0.16]$} \\
& Guadiana & 0.664 & 0.002 & 0.412 & -0.009 & -0.18 & {$[-0.21-0.16]$} \\
& Tajo & 0.714 & 0.003 & 0.466 & -0.056 & -0.27 & {$[-0.32-0.21]$} \\
\hline \multirow{6}{*}{ Grapes } & Duero & 0.651 & 0.002 & 0.399 & -0.054 & -0.23 & {$[-0.29-0.19]$} \\
& Ebro & 0.642 & 0.002 & 0.408 & -0.028 & -0.23 & {$[-0.27-0.18]$} \\
& Guadalquivir & 0.769 & 0.001 & 0.444 & 0.025 & -0.10 & {$[-0.17-0.08]$} \\
& Guadiana & 0.3642 & 0.004 & 0.395 & 0.303 & -0.27 & {$[-0.44-0.15]$} \\
& Tajo & 0.644 & 0.003 & 0.522 & 0.045 & -0.28 & {$[-0.34-0.23]$} \\
\hline \multirow{5}{*}{ Olives } & Guero & 0.694 & 0.008 & 0.500 & -0.167 & -0.91 & {$[-0.79-0.32]$} \\
& Ebro & 0.720 & 0.002 & 0.539 & 0.077 & -0.18 & {$[-0.32-0.09]$} \\
& Guadalquivir & 0.609 & 0.003 & 0.426 & -0.009 & -0.35 & {$[-0.39-0.31]$} \\
& Guadiana & 0.550 & 0.004 & 0.403 & -0.011 & -0.46 & {$[-0.64-0.23]$} \\
& Tajo & 0.485 & 0.005 & 0.412 & -0.029 & -0.50 & {$[-0.61-0.42]$} \\
\hline
\end{tabular}

\subsection{Simulations of drought-driven production changes}

Table 5 shows the Gini coefficient for the total income, and the marginal effects of the increase of drought on the farms' income distribution for the main river basins in Spain. We observe that the most unequal distribution of incomes is presented in the Duero river basin for cereals, in the Guadiana for grapes, and in the Tagus river basin for olives. We find that the increase in drought occurrence will reduce the Gini index in all the cases studied, meaning it will increase the inequality for the rural incomes. Although the effects are not large, they are mostly significant.

The estimation of the percentage change of this rural inequality allows us to explain the changes in the Gini index as a response to changes in the precipitation patterns due to climate change.

Figure 3 shows the marginal effects on production and changes in income distribution. While the impacts on average production in monetary terms depend on the crop and the location, showing a negative or positive impact, we observe that the changes in the Gini index values are always expected to be negative and they are lower in magnitude; that is, the expected effects on inequality point towards a worse situation in the context of climate-change-induced extreme events such as drought. The magnitude depends on the crop type. We observe that olives are the crop with the highest probability of having higher risk and also of generating more inequality in rural areas, while the opposite is evident for grapes. The grape industry in Spain is highly technified and can be described as a very intensive crop system. This makes a difference in terms of the effects of climate change. Aspects such as improvements in varieties are not observed in the database but are observed by the farmers, and so considered within the model as unobservable effects increasing produc-

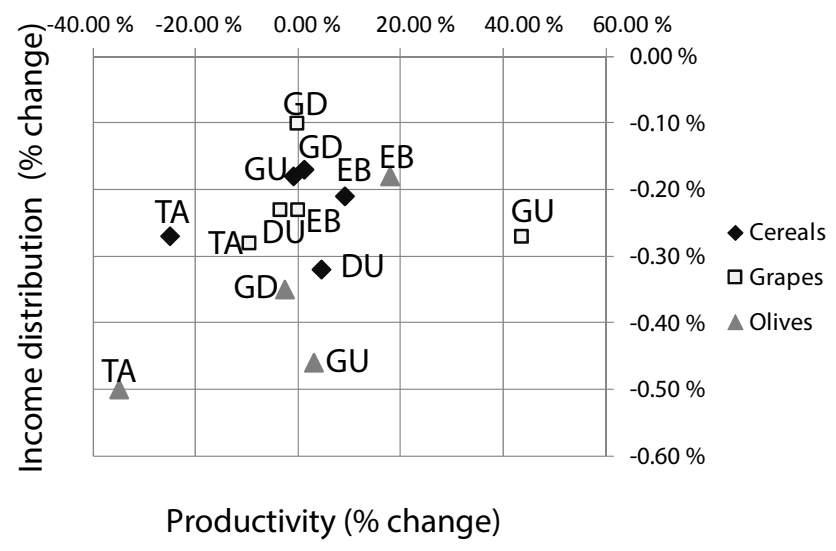

Figure 3. Marginal effects of drought events on crop production and income distribution for the selected crops in the main river basins in Spain.

tivity. This kind of effect can also increase the adaptive capacity of the system; therefore we see very different results in this industry with a higher adaptive capacity, which implies less vulnerability to change in climate extremes. On the other hand, olive and cereal crops are crops that are more extensive, labour-based, and for which fewer technical systems are used, which make them more dependent on climate factors. We observe that the Tagus river basin is the one where the greatest impact is noted due to droughts. These marginal effects can be used as a basis for understanding the priorities in adaptation policy. The impacts on cereals are highly dependent on the location. Since our analysis suggests some losses due to the marginal effect of drought on production, this could affect competitiveness in the long term. From the economic point of view, the long term is not linked to a spe- 

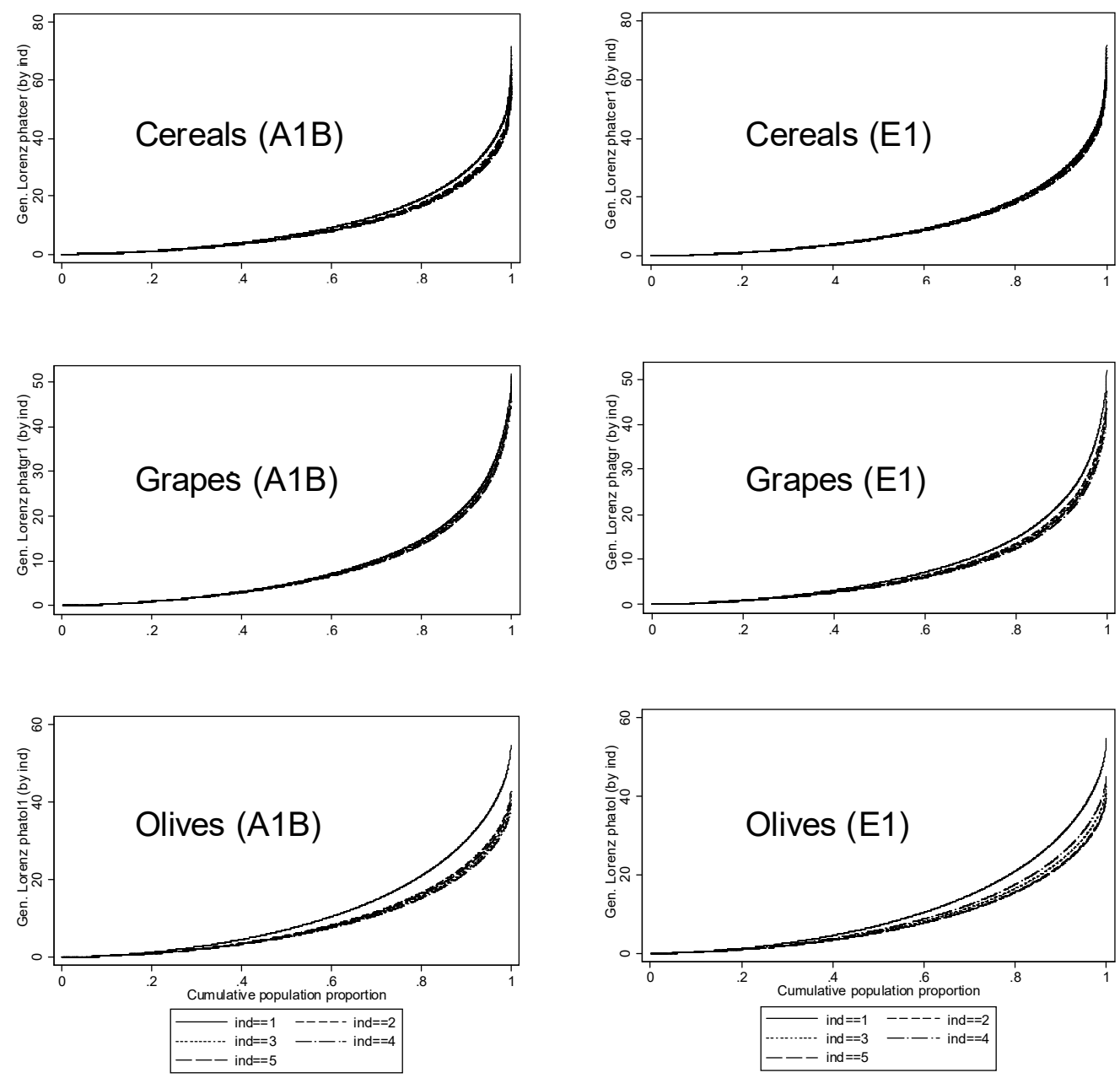

Figure 4. Lorenz curves (Gini index) for the selected crops under the baseline (1990-2013) and climate change scenarios (A1B, E1); (1) baseline, (2-5) climate change scenarios.

cific timescale, but it is considered when farms are able to adjust all costs, whereas in the short term, farms are only able to influence prices through adjustments made to production levels. Since our model considers investment responding to the final outcome, these production losses can influence investment, especially in the Tagus river basin. Since Fig. 3 suggests that different crops and regions have different expected marginal effects (i.e. income losses), different priorities should be given for defining public support for adaptation.

The effect on income distribution seems to be low in magnitude and this can be due to some compensation through market prices. This result appears to indicate that the mitigation of agricultural losses is being compensated through the worsening of consumer welfare. Here we do not calculate this effect, but we find that it would be interesting to extend the effects on consumption for future research. Some results can be found in literature in terms of changes in certainty equivalent wealth for producers and based on yields $\left(\mathrm{th}^{-1}\right)$
(Ciscar et al., 2011; Quiroga and Iglesias, 2009) but less attention has been placed on consumer income.

\subsection{Evolution of income distribution as a response to drought}

From the marginal effect on income distribution we have simulated its evolution as a response to changes in potential drought and climate variables through temperature and precipitation forecasting in the different climate change scenarios selected for the study (see Sect. 2.4). Figure 4 shows the resulting Lorenz curves (Gini index representation) to analyse how rural inequality responds to climate-change-induced drought. As we have mentioned in the methodology, the Lorenz curves represent the cumulative distribution function of income distribution. The greater the difference between the line and the so-called perfect equality or equi-distribution line, the higher the Gini index and the worse the distribution of incomes. In Fig. 4 we show the evolution of the curve from the baseline (1990-2013) to the climate change scenarios for 
2080 (A1B and E1 concentration pathways simulated by four different climate models and downscaling).

These curves show for the bottom percentage of farmers ( $x$ axis), what percentage of the total agricultural income ( $y$ axis) they have, and what percentage can be considered a measure of inequality. We observe that the effects are not huge in terms of income distribution, but they are negative for all the crops and for the different scenarios, so climatechange-induced drought increase will definitely worsen rural inequality. In addition, we observe that the sector in which the income inequality will rise is the olive sector, followed by the cereals sector. In the case of grape production, the simulated effect on inequality is not significant. Since drought events will be suffered by all the farmers independently of their income level, our results suggest that at least in rainfed crops, investment, which is mostly made by farmers with higher incomes, would not be enough to compensate the expected losses, because in other cases we will expect a very critical effect on income distribution as a consequence of drought. Although the EU White paper for adaptation (COM, 2009) indicates that there is great room for adaptation in the agricultural sector, these results suggest that in the case of drought, the adaptation measures should prioritize water resource management. A limitation of this study is the fact that we do not analyse the effects on irrigated crops. The challenge for this kind of analysis is that data on spatial resolution for water availability have to be linked to information at the farm level. In a further step, remote sensing methods could help to better characterize information on water use.

We observe in Fig. 4 that the projected scenarios are very similar for the different models considered; that is, the results we obtain for income distribution changes are very robust in terms of the different models considered. Slightly larger differences appear among the different mitigation targets (A1B and E1). In Table 6 we have analysed these differences, considering the quantification of uncertainty in our model as well. We have computed the mean-comparison test for the projected income distribution response to climate scenarios in relation to the current climate baseline. We show the $t$ statistic and $p$ value for the null hypothesis of having no significant differences among the scenarios with respect to the baseline. A $p$ value over $10 \%$ means that the results show no statistical significant differences in inequality, while the opposite applies when the $p$ value is less than $10 \%$. We observe that only some of the scenarios considering A1B concentration pathways produce significant effects on income distribution. Although the olive crop shows a bigger effect at a glance, we can see that considering the uncertainty of the model, these impacts are not significant (this is due to a bigger standard error in the model of this crop). The scenarios for the A1B concentration pathways have a bigger effect on income distribution than those for the E1 concentration pathways, both in magnitude and confidence level; so mitigation policies can help to reduce the effects of climate change on social equity.
Here we do not explicitly analyse rural communities, but income distribution at the farm level. However, we think that a worsening in the distribution of farms' incomes will affect social issues in these rural communities. We observe that the most important effects are expected on the olive crop in the southern areas in Spain. The increase in income inequality in these rural communities can be very important in terms of social conflicts since this region is mostly based on agricultural outcomes with very low development of industry. This problem we find in Spain could be the same in other Mediterranean countries where southern areas are also very much driven by the olive crop sector. Another limitation in this study is that we do not explicitly consider the role of CAP subsidies which are in fact very important, particularly in this area. Further analysis could include separated incomes from market and from CAP subsidies to explicitly examine the agricultural policy effects. However, since farm income and its distribution seem to be affected by climate change and drought challenges, the role of CAP seems to be revised in order to help competitiveness and income redistribution functions.

Here we consider the contribution of the studied crops to farmers' production and the effect of these losses on income distribution. However, we do not analyse cross-compensation or adaptation measures explicitly (i.e. crop rotation, change in varieties, part-time non-agricultural incomes, etc). Farmers of course can make several important decisions to adapt to the expected losses and it would be interesting in further analyses to take these compensation effects on income disparities into account. Therefore, adaptation measures should be designed considering both economic and social aspects.

\section{Discussion and conclusions}

This paper focuses on the effects of droughts and climate change on agricultural production and rural income distribution. We have estimated the drivers for production in monetary units and we find that traditional inputs such as labour, capital, and intermediate consumptions (energy, fertilizers, pesticides, etc.) positively affect production as expected. However, there are also nature state variables, such as drought, temperature increase, or precipitation decreases, which are not controlled by the farmers, but can produce important productivity shocks. We have estimated the elasticity for these shocks and we have especially focused on drought effects on productivity losses.

The relatively complex methodology used allows us to focus on the economic aspects of climate change and drought impacts on agriculture. We estimate directly in monetary units. For this purpose, we used economic information about marketable outputs and inputs (such as cost of labour, capital, intermediate consumptions - energy, fertilizers, etc.) in monetary terms. However, there are other factors such as soil quality or farmer's effort that are not causing a marginal cost 
Table 6. Mean-comparison test ( $t$ statistic and $p$ value for H0: mean differences $=0$ ) for the income distribution responding to the different climate change scenarios with respect to the current climate baseline.

\begin{tabular}{|c|c|c|c|c|c|c|c|}
\hline \multirow[t]{2}{*}{ Emission scenario } & \multirow[t]{2}{*}{ GCM model/downscaling } & \multicolumn{2}{|c|}{ Cereals } & \multicolumn{2}{|c|}{ Grapes } & \multicolumn{2}{|c|}{ Olives } \\
\hline & & $t$ stat & $p$ value & $t$ stat & $p$ value & $t$ stat & $p$ value \\
\hline A1B & BCM2_1 & 1.91 & 0.06 & 1.41 & 0.15 & 0.00 & 0.99 \\
\hline A1B & CNCM3_1 & 2.71 & 0.01 & 1.92 & 0.06 & -1.00 & 0.31 \\
\hline A1B & DMIEH5_4 & 3.36 & 0.00 & 2.71 & 0.01 & -2.12 & 0.03 \\
\hline A1B & EGMAM_1 & 2.72 & 0.00 & 2.16 & 0.03 & 0.22 & 0.82 \\
\hline E1 & BCM2_1 & 0.33 & 0.74 & 0.52 & 0.60 & 0.02 & 0.97 \\
\hline E1 & CNCM3_1 & 0.58 & 0.56 & 0.56 & 0.57 & 0.14 & 0.89 \\
\hline E1 & DMIEH5_4 & 0.65 & 0.51 & 0.71 & 0.47 & 0.65 & 0.51 \\
\hline E1 & EGMAM_1 & 1.52 & 0.12 & 1.20 & 0.23 & -0.42 & 0.67 \\
\hline
\end{tabular}

Note: white cells indicate no significant differences. Bold values indicate significant differences at the $10 \%$ level.

in terms of input, but have an important effect on the production. The Olley-Pakes method allows us to consider these unobservable factors and obtain non-biased estimations, although these factors are not directly considered as explanatory variables.

According to previous literature, the losses produced by drought conditions are crop-specific and they depend on location. The same can be shown in this analysis (Parry et al., 2004; Iglesias et al., 2012a; Lobell et al., 2008). The climate-change-induced and drought-induced losses in physical yields $\left(\mathrm{th}^{-1}\right)$ have been largely analysed in the literature, and they are expected to be very high for some of the crops analysed here, especially in the southern and eastern regions in Spain. However, the analysis of incomes has not captured so much attention. As we have mentioned in the text, the changes in production in monetary terms, although also crop- and location-specific, are not as high as those estimated in actual quantities yielded. Of course, in market economies, prices are expected to play a role adjusting the scarcity in physical goods, and this seems to be exactly the case here. Even when international agricultural goods are present, market prices seem to respond to yield losses at the local level and incomes are affected, though to a lesser degree. This is very important because it transfers the affected community from being producers to consumers.

With regard to income distribution we have estimated the marginal effects of drought on the Gini coefficient and we have observed that the effects are not large but they are negative for all the crops analysed whatever the river basin considered. The Tagus river basin is the one that shows the most important effects in both production loss and income inequality, and with respect to the sectors analysed, the olive sector is where the greatest impacts are noted. The results are policy-relevant since adaptation policy for agricultural systems and water resource distribution could consider prioritizing the most affected basins and sectors.

When simulating climate change conditions our results show that income distribution can be expected to get worse, although the effects are higher on the production loss than on the inequality increase. The scenarios based on A1B concentration pathways produce higher effects on income distribution than those based on E1 concentration pathways, so mitigation policies can reduce the vulnerability of low-income rural communities.

The results achieved are relevant since although the relationship between climate change and inequality has been identified to be very important (IPCC, 2014; UNDP, 2010; López-Feldman, 2015), there are still few empirical studies quantifying the effects on income distribution. Most of the studies addressing distributional aspects are based on food security - yields or ingested calories, poverty or development indicators. These kinds of studies are very important and pertinent in order to analyse the global situation where developed and non-developed countries are present. However, in the context of the EU or the OECD developed countries, sometimes these kinds of measures (literacy levels, access to water, ingested calories, etc.) are not adequate enough to describe the situation of a loss in income distribution. For this reason, we find that our results can provide a better picture for analysing the worsening situation of farmers in developed countries, since they address the direct impacts considering farmers' incomes in real terms. We have found that the differences in terms of income distribution are not as severe as those reported in studies that analyse solely physical impacts (Iglesias et al., 2010), which suggests an important role of market prices in stabilizing farmers' outcomes. Although most of the studies project important crop production to be reduced due to climate change in Spain (Iglesias et al., 2012a; López-Gunn et al., 2012), our results could imply rural incomes not suffering the most through agriculture losses but consumers' welfare being the most greatly affected. We have not analysed consumers' welfare here directly. However, since important effects on crop production can be expected while we do not predict very big impacts on income, probably, this lack of expected impacts is due to a 
smoothing effect through prices, which in fact highly affects consumers' welfare.

Concerning adaptation, we have found that the Tagus river basin is the most affected region with regard to changes in the average income of farmers. This would imply that larger efforts for adaptation should be made in this area, where water resources' management becomes a key element for adaptation. Tagus river basin has been pointed to be one of the basins where pressures will be increased to a more substantial degree in terms of unsatisfied demand. Having the highest magnitude effects in terms of monetary outcomes and consequences on inequality will increase the already existing conflicts among different water users and water management challenges including potential changes in the interbasin water transfer schemes with the Segura river basin. A total of $9.8 \mathrm{~km}^{3}$ of water has been transferred in 30 years, during which the interbasin water transfer has been operative. Of this, $60 \%$ has been used for irrigated agriculture in the southeast region in Spain; $38 \%$ has been dedicated to complement drinking water supply in the region; other uses include transfer water to the Tablas de Damiel National Park, a wetland ecosystem in the Guadiana River basin (Pittock et al., 2009). Therefore, the increasing pressures do not only have implications for socio-economic issues, but also on the ecosystem.
Moreover, we have found that the olive sector should be considered as a priority in terms of both farms' incomes and social equity. Studying the role of CAP subsidies will be important to address this challenge in the future. The olive sector is the most important agricultural sector in the south of the Mediterranean and represents an important factor for rural development in the area. Olive oil farms in Spain are on average bigger and have a higher labour productivity than elsewhere. Labour is the most important cost for these farms, the family labour representing around $50 \%$ of total costs. In addition, olive farms in Spain have suffered on average unfavourable trends in income indicators, with income falling by about a third in the last decades (EU FADN, 2012). Therefore, the predicted increase in inequality could increase migration out of the rural areas, affecting land use and rural development in Spain. 
Appendix A: Agricultural production function simultaneous estimates: observed inputs and unobserved productivity shocks

The Olley and Pakes (1996) approach assumes that incumbent farms decide at the beginning of each period whether to continue to participate in farming activity, a decision made according to their productivity level, which in turn depends on each farm's production factor (it corrects the selection bias). To this end, investment $\left(i_{i t}\right)$ is considered as a proxy for the unobserved productivity shocks. In addition, this method corrects the simultaneity bias arising from the fact that farms choose their level of input once they know their level of productivity.

We assume that farmers produce a homogeneous product with Cobb-Douglas technology, and that the factors underlying profitability differences among firms are neutral efficiency differences. The production function is

$y_{i t}=\beta_{0}+\beta_{l} l_{i t}+\beta_{m} m_{i t}+\beta_{k} k_{i t}+\beta_{a} a_{i t}+\sum_{j} \delta_{j} c_{j i t}+u_{i t}$

$u_{i t}=\Omega_{i t}+\eta_{i t}$,

where $y_{i t}$ is the $\log$ output for farm $i$ in period $t ; l_{i t}, m_{i t}$, $k_{i t}$ and $a_{i t}$ are the log values of labour, material, capital, and land inputs; $c_{j i t}$ are biophysical variables (climate and river basin); $\Omega_{i t}$ is the productivity shock that is observed by the farm but not by the econometrician (for example machine breakdowns); and $\eta_{i t}$ is an unexpected productivity shock that is unobserved by both the decision-maker and the econometrician. Thus, $\Omega_{i t}$ and $\eta_{i t}$ are unobserved. The distinction is that $\Omega_{i t}$ is a state variable in the farm's decision problem, and hence a determinant of both liquidation and input demand decisions, while $\eta_{i t}$ is not (see Petrick and Kloss (2013) for an extended typology of farm production factors).

Simultaneity exists between the choice of inputs and productivity since productive farms are more likely to make capital investments to increase the future value of the farm. Then, the farm's decision to invest in further capital, $i_{i t}$, also depends on capital stock, land, and the firm's productivity shock:

$i_{i t}=I\left(\Omega_{i t}, k_{i t}, a_{i t}\right)$.

This investment decision equation implies that future productivity is increasing in the current productivity shock, so farms that experience a large positive productivity shock in period $t$ will invest more in period $t+1$.

The Olley and Pakes (1996) semiparametric method accounts for these issues. Applying this method first involves using the investment decision function to control for the correlation between the error term and the inputs. This is based on the assumption that future productivity is strictly increasing with respect to $\Omega_{i t}$, so farms that observe a positive productivity shock in period $t$ will invest more in that period, for any $k_{i t}$ and $a_{i t}$. Provided that $i_{i t}$ is strictly positive, we can write the inverse function for the unobserved shock $\Omega_{i t}$ as

$\Omega_{i t}=h\left(i_{i t}, k_{i t}, a_{i t}\right)$.

This function can thus be used to control for the simultaneity problem. Substituting those equations into production function yields

$y_{i t}=\beta_{l} l_{i t}+\beta_{m} m_{i t}+\sum_{j} \delta_{j} c_{j i t}+\varphi\left(i_{i t}, k_{i t}, a_{i t}\right)+\eta_{i t}$,

where

$\varphi\left(i_{i t}, k_{i t}, a_{i t}\right)=\beta_{0}+\beta_{k} k_{i t}+\beta_{a} a_{i t}+h\left(i_{i t}, k_{i t}, a_{i t}\right)$.

We approximate $\varphi($.$) with a second-order polynomial series$ in land, capital, and investment. The partially linear equation can be estimated by ordinary least squares. The coefficient estimates for variable inputs (labour and material) will be consistent and asymptotically normal estimates of the coefficients in the linear part of the model (Andrews, 1991) because $\varphi$ (.) controls for unobserved productivity, and thus the error term is no longer correlated to the inputs. This allows us to estimate $\beta_{l}$ and $\beta_{m}$ without requiring identification of $\beta_{k}$ and $\beta_{a}$, so more work is required to disentangle the effects of capital and age on the investment decision from their effect on output.

There is also a selection bias since farms only stay in business if the liquidation value is smaller than the anticipated future value of profits. Achieving this requires a second step to estimate survival probabilities $\left(P_{i t}\right)$, which will then allow us to control for selection bias. In our implementation, we estimate the probability of survival by fitting a probit model on $i_{i, t-1}, k_{i, t-1}, a_{i, t-1}$, as well as their squares and cross products. This can be viewed as a nonparametric estimator of the index function. If the predicted probabilities from this model are $\hat{P}_{i t}$,

$\operatorname{Pr}\left(\chi_{i t}=1\right)=\phi\left(i_{i, t-1}, k_{i, t-1}, a_{i, t-1}\right)$.

In the third step, we identify the coefficient $\beta_{k}$, where productivity is assumed to evolve according to a first-order Markov process. We fit the following equation by non-linear least squares in order to obtain $\beta_{k}$ :

$$
\begin{aligned}
& y_{i t}-\widehat{\beta}_{l} l_{i t}-\widehat{\beta}_{m} m_{i t}-\sum_{j} \hat{\delta}_{j} c_{j i t}=\beta_{k} k_{i t}+\beta_{a} a_{i t} \\
& \quad+g\left(\hat{\varphi}_{t-1}-\beta_{k} k_{i, t-1}-\beta_{a} a_{i, t-1}, \hat{P}_{i t}\right)+\xi_{i t}+\eta_{i t},
\end{aligned}
$$

where the unknown function $g($.$) is approximated by a$ second-order polynomial in

$\hat{\varphi}_{t-1}-\beta_{k} k_{i, t-1}-\beta_{a} a_{i, t-1}$ and $\hat{P}_{i t}$.

Finally, we use the efficient coefficients' estimates to build a measure of farm-level production for the $i$ farm at the time $t$. 


\section{Appendix B: Measuring rural income distribution: a decomposition of the Gini index on equity}

To characterize the size of inequality of the agricultural output, we use the Gini coefficient decomposition proposed by Pyatt et al. (1980) and Shorrocks (1982). As developed in López-Feldman et al. (2007), each source's contribution to the Gini coefficient could be observed as the product of its share on total output, its own source's Gini coefficient, and its correlation with the total output and can be expressed as

$G_{\mathrm{tot}}=\sum_{k=1}^{K} S_{k} G_{k} R_{k}$

where $G_{\text {tot }}$ represents the Gini coefficient for the total yield; $S_{k}$ is the share of component $k$ in the total yield; this brings up the question of how important the source is with respect to total yield. $G_{k}$ represents the relative Gini of source $k$, this part attempts to measure how equally or unequally distributed the income source is; $R_{k}$ is the Gini correlation between yield from source $\mathrm{k}$ and the total yield distribution $R_{k}=\operatorname{Cov}\left\{y_{k} F(y)\right\} / \operatorname{Cov}\left\{y_{k} F\left(y_{k}\right)\right\}$, which leads to the question of how the income source and the distribution of total income are correlated. This decomposition of the Gini coefficient is a good measure to help us understand the determinants of inequality, and allows us to estimate the effect of small changes in a specific source of yield (income) on inequality, maintaining the other sources at a constant level. Consequently, the decomposition of the overall Gini into specific source factor effects was derived from Lerman and Yitzhaki (1985). The authors show that the partial derivative of the overall Gini coefficient with respect to a percent change e in the source factor $k$ is equal to $\frac{\partial G_{\mathrm{tot}}}{\partial e_{k}}=S_{k}\left(G_{k} R_{k}-G_{\mathrm{tot}}\right)$.
In this paper we include drought as a source factor. As we mentioned before, if we consider the relationship between drought and crop yield, the interpretation of this decomposition will be the following: if drought source represents a large share of total crop yield, it could probably have a large impact on inequality. If crop yield is equally distributed $\left(G_{k}=0\right)$, it cannot affect inequality, even if its magnitude is large. However, if this crop yield source is large and unequally distributed ( $S_{k}$ and $G_{k}$ are large), it could either increase or decrease inequality, depending on which farmers, at which points in the crop yield distribution, earn it. If the crop yield source (drought) is unequally distributed and flows disproportionately towards those at the top of the crop yield distribution ( $R_{k}$ is positive and large), its contribution to inequality will be positive. However, if it is unequally distributed but targets poor farmers, the crop yield source may have an equalizing effect on crop yield distribution. 
Acknowledgements. This research has been supported by the project "Economic valuation of climate change adaptation in the Spanish hydrological resources sector" funded by Fundación Biodiversidad within the programme: Climate Change and Environmental Quality. Ref. Q2818014I.2014-2015.

Edited by: P. Lionello

Reviewed by: M. M. Michetti and two anonymous referees

\section{References}

Ackerberg, D., Caves, K., and Frazer, G.: Structural Identification of Production Functions, MPRA Paper 38349, University Library of Munich, Munich, Germany, 2006.

Andrews, D. W. K.: Asymptotic normality of series estimators for nonparametric and semiparametric regression models, Econometrica, 59, 307-345, 1991.

Beilin, R., Lindborg, R., Stenseke, M., Pereira, H. M., Llausàs, A., Slätmo, E., Cerqueira, Y., Navarro, L., Rodrigues, P., Reichelt, N., Munro, N., and Queiroz, C.: Analysing how drivers of agricultural land abandonment affect biodiversity and cultural landscapes using case studies from Scandinavia, Iberia and Oceania, Land Use Policy, 36, 60-72, 2014.

Blalock, G. and Gertler, P. J.: Learning from exporting revisited in a less developed setting, J. Dev. Econ., 75, 397-416, 2004.

Breunig, R. and Wong, M.: A richer understanding of Australia's productivity performance in the 1990s: improved estimates based upon firm-level panel data, Econ. Rec., 84, 157-176, 2008.

Brewer, A.:. The Making of the Classical Theory of Economic Growth, Routledge, New York, USA, 2010.

Christensen, O. B., Goodess, C. M., Harris, I., and Watkiss, P.: European and global climate change projections: discussion of climate change model outputs, scenarios and uncertainty in the EC RTD climate cost project, in: The ClimateCost Project, Final Report, Volume 1: Europe, edited by: Watkiss, P., Stockholm Environment Institute, Stockholm, Sweden, 1-27, 2011.

Ciscar, J. C., Iglesias, A., Feyen, L., Szabo, L., van Regemorter, D., Amelung, B., Nicholls, R., Watkiss, P., Christensen, O. B., Dankers, R., Garrote, L., Goodess, C. M., Hunt, A., Moreno, A., Richards, J., and Soria, A.: Physical and economic consequences of climate change in Europe, P. Natl. Acad. Sci. USA, 108, 26782683, 2011.

COM: White Paper: Adapting to climate change: Towards a European framework for action, Commission of the European Communities, Brussels, Belgium, 2009.

De Stefano, L.; Hernández-Mora, N.; López Gunn, E.; Willaarts, B.; Zorrilla-Miras, P.: Public Participation and transparency in water management, in: Water, Agriculture and the Environment in Spain: can we square the circle?, edited by: De Stefano, L. and Llamas, R., Taylor and Francis, London, UK, 217-226, 2013.

EU FADN: EU olive oil farms report Based on FADN data, European Commission EU FADN, Brussels, Belgium, 2012.

Garrote, L., Flores, F., and Iglesias, A.: Linking drought indicators to policy: the case of the Tagus Basin drought plan, Water Resour. Manag., 21, 873-882, 2007.
González-Zeas, D., Quiroga, S., Iglesias, A., and Garrote, L.: Looking beyond the average agricultural impacts in defining adaptation needs in Europe, Reg. Environ. Change, 14, 1983-1993, 2014.

Hall, R.: The relation between price and marginal cost in U.S. industry, J. Polit. Econ., 96, 921-947, 1988.

Haughton, J. and Khandker, S. R.: Handbook on Poverty and Inequality, World Bank, Washington, USA, 2009.

Iglesias, A. and Quiroga, S.: Measuring the risk of climate variability to cereal production at five sites in Spain, Clim. Res., 34, 45-57, 2007.

Iglesias, A., Quiroga, S., and Schlickenrieder, J.: Climate change and agricultural adaptation: assessing management uncertainty for four crop types in Spain, Clim. Res., 44, 83-94, 2010.

Iglesias, A., Garrote, L., Quiroga, S., and Moneo, M.: A regional comparison of the effects of climate change on agriculture in Europe, Climatic Change, 112, 29-46, 2012a.

Iglesias, A., Quiroga, S., Moneo, M., and Garrote, L.: From climate change impacts to the development of adaptation strategies: Challenges for agriculture in Europe, Climatic Change, 112, 143-168, 2012b.

IPCC: Climate Change 2007: The Physical Science Basis, Contribution of Working Group I to the Fourth Assessment Report of the Intergovernmental Panel on Climate Change, edited by: Solomon, S., Qin, D., Manning, M., Marquis, M., Averyt, K., Tignor, M. M. B., Miller Jr., H. L., and Chen, Z., Cambridge University Press, Cambridge, U.K., and New York, 2007.

IPCC: Climate Change 2014: Synthesis Report, Contribution of Working Groups I, II and III to the Fifth Assessment Report of the Intergovernmental Panel on Climate Change, Core Writing Team/edited by: Pachauri, R. K. and Meyer, L. A., IPCC, Geneva, Switzerland, 2014.

Kazukauskas, A., Newman, C., and Thorne, F.: Analysing the Effect of Decoupling on Agricultural Production: Evidence from Irish Dairy Farms using the Olley and Pakes Approach, German Journal of Agricultural Economics, 59, 144-157, 2010.

Keyantash, J. and National Center for Atmospheric Research Staff (Eds): The Climate Data Guide: Standardized Precipitation Index (SPI), available at: https://climatedataguide.ucar. edu/climate-data/standardized-precipitation-index-spi, last access: May 2016, 2015.

Lerman, R. and Yitzhaki, S.: Income Inequality Effects by Income Source: A New Approach and Applications to the United States, Rev. Econ. Stat., 67, 151-156, 1985.

Levinsohn, J. and Petrin, A.: Estimating production functions using inputs to control for unobservables, Rev. Econ. Stud., 70, 317341, 2003.

Lewellen, W. and Badrinath, S. G.: On the measurement of Tobin's $q$, J. Financ. Econ., 44, 77-122, 1997.

Lobell, D. B., Burke, M. B., Tebaldi, C., Mastrandrea, M. D., Falcon, W. P., and Naylor, R. L.: Prioritizing climate change adaptation needs for food security 2030, Science, 319, 607-610, 2008.

Lobell, D. B., Roberts, M. J., Schlenker, W., Braun, N., Little, B. B., Rejesus, R. M., and Hammer, G. L.: Greater Sensitivity to Drought Accompanies Maize Yield Increase in the U.S. Midwest, Science, 344, 516-519, doi:10.1126/science.1251423, 2014. 
López-Feldman, A.: Cambio climático, distribución del ingreso y la pobreza: El caso de México, CEPAL, Documentos de Proyectos No. 555, 2015.

López-Feldman, A., Mora, J., and Taylor, J. E.: Does natural resource extraction mitigate poverty and inequality? Evidence from rural Mexico and a Lacandona Rainforest Community, Environ. Dev. Econ., 12, 251-269, 2007.

Lopez-Gunn, E., Zorrilla, P., Prieto, F., and Llamas, M. R.: Lost in translation? Water efficiency in Spanish agriculture, Agr. Water Manage., 108, 83-95, 2012.

MAGRAMA: Anuario de Estadística, Avance 2014, MAGRAMA, Madrid, available at: http://www.magrama.gob.es/estadistica/ pags/anuario/2014-Avance/AE_2014_Avance, last access: May 2016, 2015.

Marino, E. and Ribot, J.: Special Issue Introduction: Adding insult to injury: Climate change and the inequities of climate intervention Global Environ. Chang., 22, 323-328, 2012.

Martín-Martín, C., Bunce, R., Saura, S., and Elena-Rosselló, R.: Changes and interactions between forest landscape connectivity and burnt area in Spain, Ecol. Indic., 33, 129-138, 2013.

McKee, T. B., Doesken, N. J., and Kleist, J.: The relationship of drought frequency and duration to time scales, in: Proceedings of the 8th Conference on Applied Climatology, 17-22 January 1993, Anaheim, CA, USA, 1993.

Michetti, M. and Zampieri, M.: Climate-Human-Land Interactions: A Review of Major Modelling Approaches, Land, 3, 793-833, 2014.

NDMC: What is drought?, The National Drought Mitigation Center, Lincoln, Nebraska, USA, 2015.

Olley, S. and Pakes, A.: The dynamics of productivity in the telecommunications equipment industry, Econometrica, 64, 1263-1297, 1996.

Parry, M. A., Rosenzweig, C., Iglesias, A., Livermore, M., and Fischer, G.: Effects of climate change on global food production under SRES emissions and socio-economic scenarios, Global Environ. Chang., 14, 53-67, 2004.

Pavcnik, N.: Trade liberalization, exit, and productivity improvement: Evidence from chilean plants, Rev. Econ. Stud., 69, 245276, 2002.

Petrick, M. and Kloss, M.: Synthesis Report on the Impact of Capital Use, Factor Markets Working Papers 169, Centre for European Policy Studies, Brussels, Belgium, 2013.

Piketty, T.: Capital in the 21st Century.Éditions du Seuil, Harvard University Press, Cambridge, Massachusetts, London, England, 2013.

Pindyck, R.: Climate Change Policy: What Do the Models Tell Us?, J. Econ. Lit., 51, 860-872, 2013.

Pittock, J., Meng, J., Geiger, J. M., and Chapagain, A. K.: Interbasin water transfers and water scarcity in a changing world - a solution or a pipedream? WWF Germany, 2009.

Pyatt, G., Chen, C., and Fei, J.: The distribution of income by factor components, The Quarterly Journal of Economics, 95, 451-74, 1980.

Quiroga, S. and Iglesias, A.: A comparison of the climate risks of cereal, citrus, grapevine and olive production in Spain, Agr. Syst., 101, 91-100, 2009.
Quiroga, S., Suárez, C., and Fernández-Haddad, Z.: Do water rights affect technical efficiency and social disparities of crop production in the Mediterranean?, Water, 6, 3300-3319, 2014.

Quiroga, S., Suárez, C., and Solís, J. D.: Exploring coffee farmers' awareness about climate change and water needs: smallholders' perceptions of adaptive capacity, Environ, Sci. Policy, 45, 53-66, 2015.

Rizov, M., Pokrivcak, J., and Ciaian, P.: CAP subsidies and productivity of the EU farms, Journal Agricultural Econmics, 64, 537-557, 2013.

Roeckner, E., Giorgetta, M. A., Crüger, T., Esch, M., and Pongratz, J.: Historical and future anthropogenic emission pathways derived from coupled climate-carbon cycle simulations, Climatic Change, 105, 91-108, 2011.

Rogelj, J., Meinshausen, M., and Knutti, R.: Global warming under old and new scenarios using IPCC climate sensitivity range estimates, Nature Climate Change, 2, 248-253, 2012.

Rogers, P. P., Llamas, R., Martínez-Cortina, L.: Water Crisis: Myth or Reality?, Taylor \& Francis plc., London, UK, 2006.

Rosenzweig, C., Strzepek, K., Major, D., Iglesias, A., Yates, D., Holt, A., and Hillel, D.: Water availability for agriculture under climate change: five international studies, Global Environ. Chang., 14, 345-360, 2004.

Sadras, V. O. and Bongiovanni, R.: Use of Lorenz curves and Gini coefficients to assess yield inequality within paddocks, Field Crop. Res., 90, 303-310, 2004.

Seekell, D. A., D’Odorico, P., and Pace, M. L.: Virtual water transfers unlikely to redress inequality in global water use, Environ. Res. Lett., 6, 1-6, 2011.

Shorrocks, A. F.: Inequality decomposition by factor components, Econometrica, 50, 193-212, 1982.

Solow, R.: Technical change and the aggregate production function, Rev. Econ. Stat., 39, 312-320, 1957.

Tsakiris, G., Loukas, A., Pangalou, D., Vangelis, H., Tigkas, D., Rossi, G., and Cancelliere, A.: Drought characterization, in: Drought Management Guidelines Technical Annex, Options Méditerranéennes Series B, No. 58, edited by: Iglesias, A., Moneo, M., and Lopez-Francos, A., Publisher CIHEAM/EC MEDA Water, Centro Internacional de Altos Estudios Agronómicos Mediterráneos/Euro-Mediterranean Regional Programme for Local Water Management, Zaragoza, Spain, 85102, 2007.

UNDP: Mapping Climate Change Vulnerability and Impact Scenarios, United Nations Development Programme, New York, USA, 2010.

Watkins, P., Holland, M., King, K., and Hunt, A.: Damages to land, in: Green Accounting in Europe, Volume 2: A Comparative Study, edited by: Markandya, A. and Tamborra, M., Fondazione Eni Enrico Mattei Series on Economics and the Environment, Elgar, Cheltenham, UK and Northampton, Mass., 381-410, 2005.

Wheeler, T. and von Braun, J.: Climate change impacts on global food security, Science, 341, 508-513, 2013.

Yasar, M., Raciborski, R., and Poi, B.: Production function estimation in Stata using the Olley and Pakes method, Stata J., 8, 221231, 2008. 